\title{
Euphausiids in the diet of a North Pacific seabird: annual and seasonal variation and the role of ocean climate
}

\author{
J. Mark Hipfner* \\ Centre for Wildlife Ecology, Simon Fraser University and the Canadian Wildlife Service, RR\#1 5421 Robertson Road, \\ Delta, British Columbia V4K 3N2, Canada
}

\begin{abstract}
Across the California Current System (CCS), euphausiid crustaceans are important prey for many vertebrate predators, including the seabird Cassin's auklet Ptychoramphus aleuticus. However, the effects of ocean climate on euphausiid biology, and their consequences for predators, remain poorly understood. Over a 13 yr period (1996 to 2008), Euphausia pacifica, Thysanoessa spinifera and T. inspinata cumulatively averaged about $35 \%$ of the annual biomass in the nestling diets of auklets at Triangle Island, but there was marked inter-annual variation. Whereas ocean climate had little influence on the amounts of E. pacifica or T. inspinata delivered, diets included more T. spinifera if spring sea-surface temperatures in the previous year had been lower. Cold conditions might facilitate the production of a strong annual cohort, thus increasing adult biomass in the following year. Within seasons, the amount of E. pacifica in diets declined with date, and the decline was consistent across both warm- and cold-water years. In contrast, diets were especially rich in both Thysanoessa spp. late in the provisioning period in warm-water years, when the harvest of Neocalanus cristatus declined dramatically due to a temporal mismatch between the auklet predator and this copepod prey. Both the annual nestling survival rate and the mean fledging masses of Cassin's auklets were tightly correlated to the amount of $N$. cristatus in their diets, and for fledging mass there was a further small, additive effect of increased amounts of $T$. inspinata. Results of the present study add new insight into effects of ocean climate on euphausiid biology in the northern CCS, and their potential consequences for population processes of an important euphausiid predator.
\end{abstract}

KEY WORDS: Auklet · Diet $\cdot$ Euphausiids $\cdot$ Ocean climate $\cdot$ Prey-switching

\section{INTRODUCTION}

Studies of marine ecosystem dynamics have been at the forefront of the research agenda investigating the biological consequences of climate variation (Stenseth et al. 2004). Climate-driven changes in the distribution, phenology and abundance of low trophic level organisms can have cascading effects within marine food webs, with consequences for the population dynamics of species at higher trophic levels (Anderson \& Piatt 1999, Edwards \& Richardson 2004, Richardson 2008). Studies on the demographic and behavioural responses of marine birds often provide clear signals of the mechanisms by which variation in ocean climate alters trophic pathways (Aebischer et al. 1990, Durant et al. 2003, Piatt et al. 2007). Studies of zooplanktivorous seabirds may be especially informative, because they feed on organisms within a low and narrow trophic range that often respond strongly and predictably to environmental variation (Springer \& Roseneau 1985, Bertram et al. 2001, Sydeman et al. 2001).

As a group, euphausiid crustaceans play important yet often underappreciated roles in many marine food webs (Reid et al. 2004, Richardson 2008). Across the California Current System (CCS), for example, the euphausiids Euphausia pacifica and Thysanoessa spinifera are important prey for many vertebrate predators (Brodeur \& Pearcy 1992, Ainley et al. 1996, 
Tanasichuk 2002, Brinton \& Townsend 2003, Croll et al. 2005, Suntsov \& Brodeur 2008). Research has shown that the population biology of both of these euphausiids is influenced by ocean climate (Tanasichuk 1998a,b, Marinovic et al. 2002, Brinton \& Townsend 2003, Dorman et al. 2005), but in a complex manner that remains poorly understood (Abraham \& Sydeman 2004). In this marine system, studies on the breeding ecology of Cassin's auklet Ptychoramphus aleuticus, a regionally abundant zooplanktivorous seabird, have provided considerable insight (Ainley et al. 1996, Sydeman et al. 2001, Adams et al. 2004).

At breeding colonies in the southern and central CCS, Euphausia pacifica and Thysanoessa spinifera are the primary prey fed to Cassin's auklet Ptychoramphus aleuticus nestlings. Over the course of the birds' spring and summer breeding season, the amount of adult E. pacifica in nestling diets tends to decrease, while the amount of juvenile and adult $T$. spinifera tends to increase (Adams et al. 2004, Abraham \& Sydeman 2006). This dietary switch is more pronounced in cold-water years (Abraham \& Sydeman 2006), appears to benefit developing offspring (Abraham 2008), and may be triggered by the onset of upwelling (Ainley et al. 1996). While the relationship is weak (Abraham \& Sydeman 2004), there is, in addition, an across-season climate signal in which E. pacifica tends to be more prevalent in diets in cold-water years than in warmwater years (Abraham \& Sydeman 2006). Further, Cassin's auklets breed less successfully in years in which there is less T. spinifera in their diets (Abraham \& Sydeman 2004), indicating the particular importance of this euphausiid prey to the auklets' population processes (Ainley et al. 1996).

The largest Cassin's auklet breeding colony in the world is located at Triangle Island, British Columbia, Canada (Rodway 1991). At this more northerly site, situated near the transition zone between the upwellingdriven CCS and the downwelling-driven Alaska Gyre system, the subarctic copepod Neocalanus cristatus averages $\sim 40 \%$ of the total biomass in the nestling diets of auklets, yet its prevalence explains a disproportionately high $\sim 80 \%$ of inter-annual variation in offspring growth and survival (Hipfner 2008). Ocean climate strongly influences the life-cycle timing of this copepod, a high-quality prey item for the auklets (Hedd et al. 2002), and, in particular, the annual spring and summer period of residency of late-stage copepodites in near-surface waters. This is the only time when they are available to Cassin's auklets. In phenologically early, warm-water years, peaks in available biomass occur too early and are too brief relative to the birds' nestling-provisioning period. As a result of the temporal mismatch, Cassin's auklets breed less successfully in warm-water years. In contrast, in pheno- logically late, cold-water years the peak in $N$. cristatus biomass is later and broader, matching well with the birds' provisioning period, and they breed more successfully as a result (Bertram et al. 2001, Hipfner 2008).

While Neocalanus cristatus appears to be particularly important prey for Cassin's auklets at Triangle Island, 3 euphausiids (Euphausia pacifica, Thysanoessa spinifera and $T$. inspinata) comprise dominant secondary prey types (Hedd et al. 2002). Together, these euphausiids average ca. 35 to $40 \%$ of the total biomass in nestling diets (Hipfner 2008). While springtime mesozooplankton biomass in this region is dominated by calanoid copepods, euphausiid biomass peaks later than that of Neocalanus spp. (Mackas 1992, Mackas et al. 2004), so that euphausiids often become important components of the diets of Cassin's auklet late in their breeding season (Hedd et al. 2002). Furthermore, they may be especially important in warmwater years, when $N$. cristatus virtually disappears from diets weeks earlier than it does in cold-water years (Bertram et al. 2001, Hipfner 2008).

At present, there is little information on the population biology of euphausiids in the northern sector of the CCS compared to in the southern and central sectors (Tanasichuk 1998a,b, Mackas et al. 2001, Lu et al. 2003). Here, I describe inter-specific, inter-annual, seasonal and age-related variation in the harvest of euphausiids by Cassin's auklets breeding at Triangle Island. The 13 yr study (1996 to 2008) spanned a period of extreme inter-annual variation in the marine environment of the NE Pacific, including 'warm-and-lowproductivity' periods in 1996 to 1998 and 2003 to 2005 and 'cool-and-high-productivity' periods in 1999 to 2002 (Mackas et al. 2007). The warm period continued through 2006, but there was a return to cold conditions in 2007 associated with La Niña that persisted through 2008 (DFO 2008). It also included extreme climate events in 1997 to 1998 (a strong El Niño), 1999 (a strong La Niña) and 2005 (an anomalous atmospheric blocking event), all of which had dramatic effects on the demography of Cassin's auklet across the CCS (Bertram et al. 2005, Sydeman et al. 2006, Lee et al. 2007, Wolf et al. 2009).

The present paper addresses a series of specific questions: (1) Does the amount of any of the 3 euphausiid species in the nestling diets of Cassin's auklets vary among years, and, if so, do ocean climatic conditions, gauged by spring sea-surface temperature, have an effect? I consider temperature in the current year, which could have short-term influences on abundance and distribution, and in the previous year, because given the comparatively long 1 to $2 \mathrm{yr}$ life cycles of euphausiids, we might expect a lag between the size of the cohort produced in Year $x$ and the size of the adult stock in Year $x+1$ (Tanasichuk 1998a,b, 
Feinberg \& Peterson 2003). (2) Are there any systematic within-season patterns in the amount of any of the 3 euphausiid species delivered by parent auklets to their offspring, and, if so, do the patterns vary with ocean climatic conditions? Abraham \& Sydeman (2006) proposed a series of hypotheses to explain seasonal prey-switching between Euphausia pacifica and Thysanoessa spinifera by Cassin's auklets, and I consider the results of the present study in relation to their hypotheses. Finally, (3) is there an additive fitness benefit in including more of any one or other of the 3 main euphausiids in nestling diets, in terms of increases in either the nestling survival rate or the annual mean fledging mass of Cassin's auklet offspring, beyond the very strong benefit of including more Neocalanus cristatus (Hipfner 2008)?

\section{MATERIALS AND METHODS}

Study area. Field work was conducted at Triangle Island, British Columbia, Canada (50 $\left.52^{\prime} \mathrm{N}, 129^{\circ} 05^{\prime} \mathrm{W}\right)$, in each year from 1996 to 2008.

Field methods. To sample the nestling diets of Cassin's auklet Ptychoramphus aleuticus, $\sim 10$ provisioning adults per session were captured while returning to the colony in darkness using pheasant nets erected between 2 large poles (600 samples in total). Sampling occurred at $10 \mathrm{~d}$ intervals, beginning on 18 May (but 28 May in 2005, 2007 and 2008) and ending on 27 June (4 to 5 sessions in total per year). This $6 \mathrm{wk}$ interval corresponds well with the nestling provisioning period of pairs that laid eggs by the population-wide median laying date in most years. Occasionally, sampling sessions had to be delayed by 1 to $3 \mathrm{~d}$, due to inclement weather, or they spanned 2 or 3 consecutive nights until 10 samples were obtained. Adult auklets carry undigested zooplankton to their young in a sublingual pouch. Upon capture, we massaged the adults' pouches to induce them to regurgitate their food loads through a funnel into a small, pre-weighed, screw-top plastic bottle, later filled with buffered formalin.

Auklet nest sites (earthen burrows) were examined at $5 \mathrm{~d}$ intervals to monitor the timing and success of auklet breeding in each year ( 80 nests in each year). Nest checks began in late March or early April, just prior to the start of laying, in all years, except 2000 and 2001, when they began in mid-April, and, in 2008, when they began in mid-May. When an egg was first found, the burrow was left undisturbed for $35 \mathrm{~d}$, then again inspected at $5 \mathrm{~d}$ intervals until a hatchling was found. When first found, hatchling wing length ( $\pm 1 \mathrm{~mm}$, using a wing bar) and mass ( $\pm 1 \mathrm{~g}$, using a $50 \mathrm{~g}$ spring scale) were measured. Hatching dates, thus nestling ages, were estimated using a calibration of wing length against age for known-aged nestlings based on earlier measurements (Hedd et al. 2002). Nestlings then were measured and weighed at ages 5 , 10,25 and $35 \mathrm{~d}$, and then every $2 \mathrm{~d}$ until they disappeared. Those that survived $\geq 35 \mathrm{~d}$ before disappearing were considered to have survived to fledge (i.e. they left the burrow to begin an independent life at sea), provided they were not later found dead in the burrow. Fledging mass was taken to be the last mass recorded prior to the chick's disappearance. In relating diet composition to offspring survival and fledging mass, I consider only offspring that hatched by 25 May ( 75\% of the entire sample) because diets through most of the developmental periods of these offspring were well covered by the 6 wk diet sampling scheme (Hipfner 2008).

Laboratory methods. Regurgitated diet samples were transferred to stacked sieves and rinsed repeatedly with water to remove preservative. Individual items present in subsamples were identified to the lowest possible taxonomic level (species for all prey items considered here), enumerated, blotted dry and weighed on an electronic balance. As in other recent studies of the diet of Cassin's auklet from the NE Pacific (Adams et al. 2004, Abraham \& Sydeman 2006), prey species were identified and enumerated by $\mathrm{M}$. Galbraith, Institute of Ocean Sciences, Sidney, British Columbia.

Statistical methods. Each individual food load collected from a provisioning Cassin's auklet parent was treated as an independent and equal sample, regardless of its size or completeness. Raw data used in the analyses were the arcsine-transformed proportions of wet biomass in individual food loads that consisted of the species being considered. First, I examined which factors affected the proportion of biomass comprised of combined adults and the much rarer juveniles of each species of euphausiids in auklet diets. As predictor variables, I used year (1 to 13), sampling session within the year (a surrogate for date; 1 to 5 ) and their interaction. For each species of euphausiid, I built a set of 5 explanatory generalized linear models (GLMs): (1) null or equal means model, (2) year, (3) session, (4) year + session and (5) year + session + year $\times$ session.

All models within each candidate set were ranked using Akaike's information criterion (AICC) corrected for small sample size, based on the difference between each model's AIC $c$ and the lowest $\mathrm{AIC} C$ from among the candidate set. In addition to selecting a single most-parsimonious model $(\triangle \mathrm{AIC} C=0.0)$, any models with $\triangle \mathrm{AIC} C$ scores $\leq 2$ can be considered to have received strong support (Burnham \& Anderson 2002).

Follow-up analyses were dictated by the results of these initial analyses. (1) For each euphausiid species 
in which year was included in a strongly supported model, I regressed the annual mean proportion of that euphausiid against the mean spring sea-surface temperature (SST) in the current year $(x)$ and in the previous year $(x-1)$, and compared the relative support for these 2 models against that for a null model. To be consistent with previous work (Bertram et al. 2001, Hipfner 2008), I used the April mean SST measured at the lighthouse at Pine Island, $\sim 100 \mathrm{~km}$ to the east of Triangle Island. Note that SST at Pine Island accurately gauges water-column temperature due to deep tidal mixing (Bertram et al. 2001); furthermore, throughout the 13 yr study period, April mean SSTs accorded very well with general accounts of oceanographic variation for the broader region (Mackas et al. 2007, DFO 2008), and correlated strongly with means in May $(\mathrm{r}=0.86)$ and June $(\mathrm{r}=0.80)$, when auklet provisioning peaks.

(2) For each euphausiid species in which session was included in a strongly supported model, I plotted the mean proportion delivered in each of the 5 sampling sessions, pooled across all years, to describe the overall seasonal pattern of delivery of each species. To account for inter-annual variation (i.e. a year effect), I calculated for each species the grand mean proportion delivered across all sessions within each year, set that annual grand mean value to zero, and then converted all raw data points within each year to deviations from the annual mean. Thus, raw data consisted of the deviations from the zero-centred mean for each of the $13 \mathrm{yr}$.

(3) For each euphausiid species in which the year $\times$ session interaction term was included in a strongly supported model, I subdivided all years into those falling within cold periods (1999 to 2002 and 2007 to 2008) and within warm periods (1996 to 1998 and 2003 to 2006), using the same zero-centred raw data. To allow for a visual comparison, I plotted the seasonal patterns of delivery in cold years versus warm years.

(4) I tested whether there was a discernible fitness benefit for the auklets in including more of any of the 3 euphausiid species in nestling diets (as a secondary prey item, after Neocalanus cristatus). As fitness measures, I used the proportion of nestlings that survived the period from hatching to fledging in each year, and their mean fledging mass. I tested the relative support for each of a series of 4 explanatory GLMs: (1) Neocalanus cristatus $+N$. cristatus $^{2}$, (2) N. cristatus $+N$. cristatus $^{2}+$ Euphausia pacifica + E. pacifica ${ }^{2}$, (3) $N$.

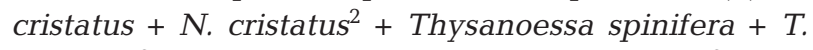
spinifera $^{2}$ and (4) N. cristatus $+N$. cristatus $^{2}+T$. inspinata $+T$. inspinata ${ }^{2}$. I included both linear and quadratic terms, to account for curvilinearity in the relationship with fledging mass.

\section{RESULTS}

\section{Ocean climate variation}

Relative to the long-term (1937 to 1995) average, mean April SSTs measured at Pine Island were very warm from 1996 through 1998, near average from 1999 to 2002, warmer than average from 2003 to 2006, then cool again in 2007 and 2008 (Fig. 1). Thus, the oceanographic periods described by others are evident in these SST data (Mackas et al. 2007, DFO 2008). Note that the present study spanned 2 transitions from generally warm to generally cool periods and 1 transition from a cool to a warm period.

\section{Neocalanus cristatus in diets}

Across the $13 \mathrm{yr}, N$. cristatus was the dominant prey item in the diets of Cassin's auklet nestlings, averaging $39.4 \%$ of biomass (range: 21.3 to $60.6 \%$ ). As expected, $N$. cristatus made up a greater proportion overall of the nestling diets of auklets in years with lower mean April SST $\left(\mathrm{r}^{2}=0.45\right.$, mean proportion $N$. cristatus $=-0.15$ mean April SST $+1.63 ; \mathrm{n}=13 \mathrm{yr}$ ), because it persisted longer in diets during cold periods (Fig. 2). Besides euphausiids, the only other prey type that comprised $>5 \%$ of the annual biomass was ichthyoplankton (annual mean: $\sim 15 \%$, including a wide range of species), and only 3 other prey types (the amphipod Vibilia propinqua, crab larvae and the caridean Pandalus mysis) comprised $\geq 2.0 \%$ of the total biomass delivered to auklet nestlings in any year.

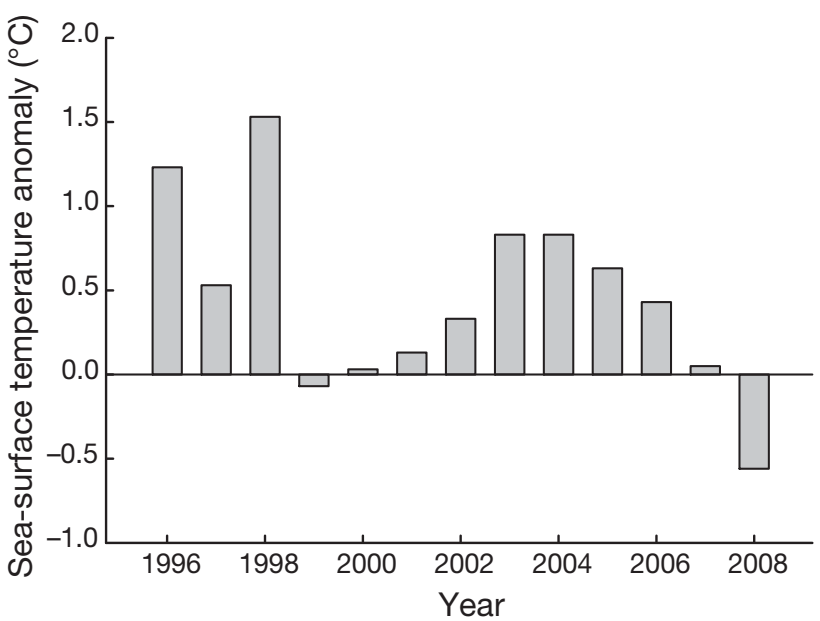

Fig. 1. Monthly (April) mean sea-surface temperature anomalies at the Pine Island light station, 1996 to 2008, expressed as deviations from the 1937 to 2005 mean (set to 0 ). Note that there were 2 warm periods (1996 to 1998 and 2003 to 2006) and 2 cool periods (1999 to 2002 and 2007 to 2008) 


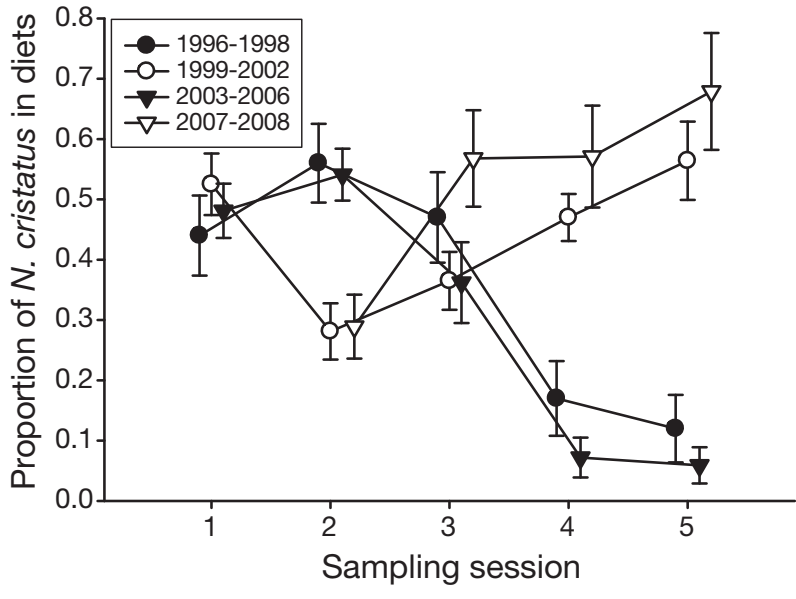

Fig. 2. Ptychoramphus aleuticus. Seasonal variation in the proportion of mean biomass ( $\pm 1 \mathrm{SE}$ ) of Neocalanus cristatus in the nestling diets of Cassin's auklets from mid-May until the end of June. Raw data were pooled across each sampling session and year within each of the 4 oceanographic periods: the warm periods from 1996 to 1998 and 2003 to 2006, and the cold periods from 1999 to 2002 and 2007 to 2008. N. cristatus persists in large amounts until later during the cold periods than the warm periods

\section{Euphausiids in the diets of auklet nestlings}

Species composition and age ratios

Considering all species combined, euphausiids comprised an average of $35.1 \%$ of the biomass in the diets of auklet nestlings across the $13 \mathrm{yr}$. The most abundant species was Thysanoessa spinifera (average: $15.6 \%$ of biomass), followed by T. inspinata (average: $9.7 \%$ ) and Euphausia pacifica (average: $9.3 \%$ ). Only 2 other species of euphausiids were recorded: 1 food load collected on 28 May 2002 contained a very small amount of adult Nematoscelis difficilis and small amounts of adult T. gregaria were present in food loads collected on 28 May, 7 and 17 June in 2004, on 28 May, 7 and 17 June in 2005, and on 18 and 28 May and 7 June in 2006 (Fig. 3).

In general, adults were much more common than juveniles in all 3 of the main euphausiid species, but there were both inter-specific and inter-annual differences. Notably, juvenile Euphausia pacifica were never recorded; juvenile Thysanoessa spinifera were relatively common compared to adults in 1996, 1998 and 1999, but rare or absent from 2000 onwards; and the biomass of juvenile $T$. inspinata exceeded that of adults from 1996 to 1998, but juveniles have not been recorded since 2001, except for a very small number in 2005 (Fig. 4). In the years when they were included in diets, juvenile T. spinifera were recorded no earlier than 7 June, with largest amounts on 27 June in 1996
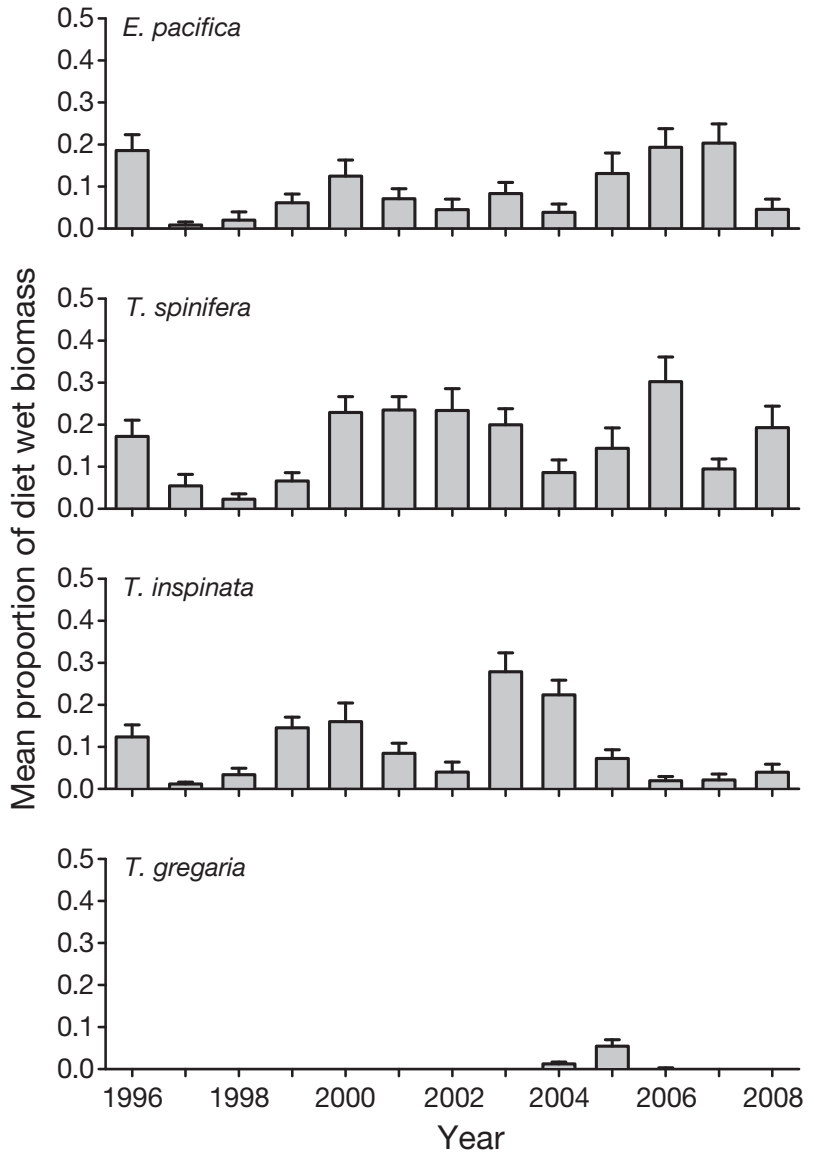

Fig. 3. Ptychoramphus aleuticus. Inter-annual variation in the proportion of mean $( \pm 1 \mathrm{SE})$ biomass across all individual food loads for the most common euphausiids (Euphausia pacifica, Thysanoessa spinifera, T. inspinata and T. gregaria) in the diets of Cassin's auklet nestlings at Triangle Island between mid-May and the end of June, 1996 to 2008. Nematoscelis difficilis was recorded in very small amounts, only in 2002

and 1999. The only exception was in the El Niño year of 1998, when T. spinifera was recorded only in small amounts and only on 18 and 28 May. Juvenile $T$. inspinata never occurred in samples collected on 18 May, but occurred at least once in all 4 later sessions.

\section{Annual variation}

There was little ambiguity in the results of $\mathrm{AIC} C$ model comparisons to assess variation in the amounts of the 3 euphausiids in nestling diets. For all 3, only 1 model received strong support $(\mathrm{AIC} C<2.0)$, and it received all of the model weight $\left(\mathrm{AIC}_{W}=1.00\right)$. The explanatory power of the top-ranked models was about 3 times better for the 2 Thysanoessa species than for Euphausia pacifica (Table 1). 


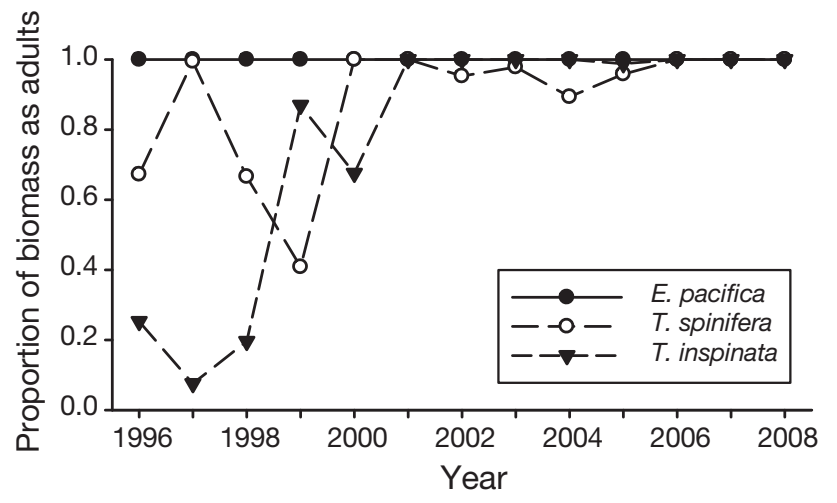

Fig. 4. Ptychoramphus aleuticus. Inter-annual variation in the proportion of total biomass made up of adults, as opposed to juveniles, for the 3 main euphausiids (Euphausia pacifica, Thysanoessa spinifera and T. inspinata) in the nestling diets of Cassin's auklets at Triangle Island between mid-May and the end of June, 1996 to 2008

For all 3 euphausiid species, the best-supported $\mathrm{AIC}_{C}$ model included year. In the case of Euphausia pacifica and Thysanoessa inspinata, the yearly variation was not linked to the ocean climate parameter examined: compared to AIC $c$ models that included the mean April SST in the current year and in the previous year, only the null model was strongly supported, and it received at least 3.3 times the weight of either climate model (Table 2). In contrast, the best-supported model for $T$. spinifera was April SST in the previous spring (Table 2): diets were richer in T. spinifera in years that followed a year with lower spring SSTs (Fig. 5).

\section{Seasonal variation}

Table 1. Ptychoramphus aleuticus. Results of AICc (Akaike's information criterion, corrected) model comparisons to explain variation in the arcsine-transformed proportion biomass of 3 euphausiids (Euphausia pacifica, Thysanoessa spinifera and T. inspinata) in 600 food loads of Cassin's auklet nestlings collected in 5 sampling sessions in each of $13 \mathrm{yr}$ at Triangle Island. For both Thysanoessa spp., the best-supported model was the global model, including year ( $Y_{i} 1$ to 13), sampling session ( $\mathrm{S}$, equivalent to date; 1 to 5 ) and their interaction; for E. pacifica, the best-supported model, which had less explanatory power, included only $\mathrm{Y}$ and $\mathrm{S}$. Note that, in each case, the top-ranked model received all of the AIC weight $(\mathrm{AICw}) . k$ : number of parameters in the model

\begin{tabular}{|lccccc|}
\hline Species & Model & $\mathrm{R}^{2}$ & $\Delta \mathrm{AIC} C$ & $\mathrm{AIC} w$ & $k$ \\
\hline E. pacifica & $\mathrm{Y}+\mathrm{S}$ & 0.11 & 0.00 & 1.00 & 20 \\
T. spinifera & $\mathrm{Y}+\mathrm{S}+\mathrm{Y} \times \mathrm{S}$ & 0.33 & 0.00 & 1.00 & 68 \\
T. inspinata & $\mathrm{Y}+\mathrm{S}+\mathrm{Y} \times \mathrm{S}$ & 0.31 & 0.00 & 1.00 & 68 \\
\hline
\end{tabular}

ods (Fig. 7), the within-season patterns of delivery varied among years for the 2 Thysanoessa species. In the case of $T$. inspinata, there was virtually no seasonal variation at all in its harvest in cold periods, while the marked increase in the middle of June was exclusively a warm-year phenomenon (Fig. 7). In the case of $T$. spinifera, the warm-water/cold-water dichotomy was not as marked as for $T$. inspinata, but this species too was clearly more important late in the season (17 and 27 June) in warm-water than in cold-water periods (Fig. 7).

\section{Fitness correlates of euphausiids in diets}

Inter-annual variation in the percentage of nestling auklets that survived from hatching to fledging (Table 3), and in their mean fledging masses (Table 4),
In addition to year, the best-supported models for all 3 euphausiid species included session (Table 1). The amount of Euphausia pacifica in diets decreased with date, while Thysanoessa spinifera increased; the auklets' harvest of $T$. inspinata was very consistent from the beginning to the end of the season, except for a sharp spike in the middle of June (Fig. 6). However, for both Thysanoessa spp., but not for E. pacifica, the best-supported models also included the interaction between year and session. Thus, whereas the trend for seasonally declining use of E. pacifica by Cassin's auklets was quite consistent from year to year and across warm and cold peri-
Table 2. Ptychoramphus aleuticus. Results of AICc (Akaike's information criterion, corrected) model comparisons to explain variation in the annual mean amount of the 3 euphausiids in food loads of Cassin's auklet nestlings at Triangle Island in $13 \mathrm{yr}$ in relation to mean April sea-surface temperature (SST) in the current year and in the previous year. For both Euphausia pacifica and Thysanoessa inspinata, the best-supported model was the null model; for $T$. spinifera, the best-supported model was April SST in the previous year, which received all of the AIC weight (AICw). $k$ : number of parameters in the model

\begin{tabular}{|lccccc|}
\hline Species & Model & $\mathrm{R}^{2}$ & $\Delta \mathrm{AIC} C$ & $\mathrm{AIC} W$ & $k$ \\
\hline E. pacifica & Null & - & 0.00 & 0.67 & 1 \\
& April SST (Year $x$ ) & 0.01 & 2.82 & 0.16 & 2 \\
& April SST (Year $x-1)$ & 0.01 & 2.84 & 0.16 & 2 \\
T. spinifera & April SST (Year $x-1)$ & 0.32 & 0.00 & 1.00 & 2 \\
& Null & - & 38.54 & 0.00 & 1 \\
T. inspinata & Null & - & 0.00 & 0.65 & 1 \\
& April SST (Year $x$ ) & 0.01 & 2.39 & 0.20 & 2 \\
& April SST (Year $x-1)$ & 0.00 & 2.83 & 0.15 & 2 \\
\hline
\end{tabular}


was explained most parsimoniously by the proportion of Neocalanus cristatus in their diets: offspring were more likely to survive, and they fledged heavier, in years in which they received more of this copepod. For survival, no model that included any of the 3

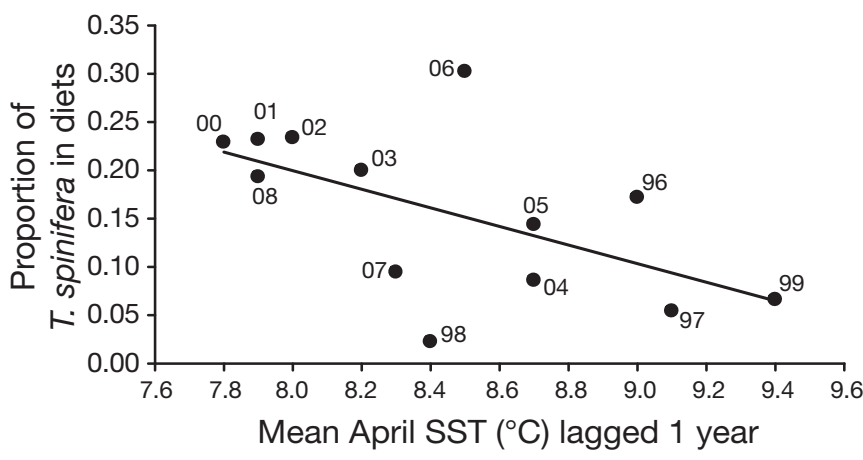

Fig. 5. Ptychoramphus aleuticus. The mean annual proportion of biomass comprised of Thysanoessa spinifera in food loads delivered by Cassin's auklet to nestlings in relation to April sea-surface temperature (SST) in the previous year. Numbers beside data points refer to the year in which euphausiids, not SST, were measured

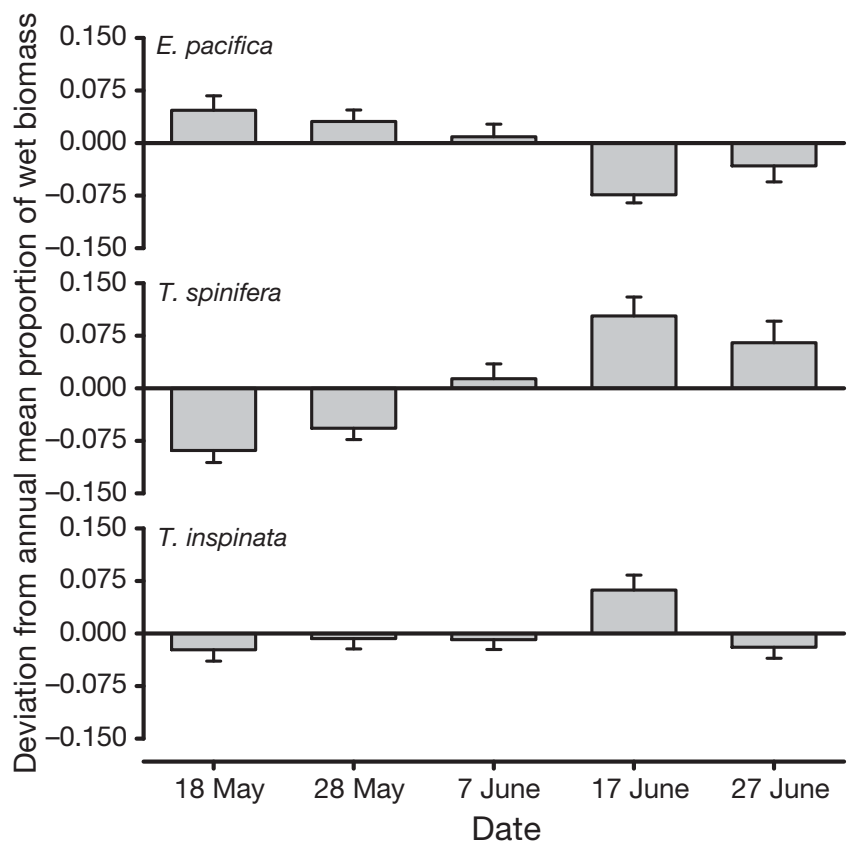

Fig. 6. Ptychoramphus aleuticus. Within-season variation in the proportion of mean biomass ( $\pm 1 \mathrm{SE}$ ) comprised of each of 3 main euphausiids (Euphausia pacifica, Thysanoessa spinifera and T. inspinata) in food loads delivered by Cassin's auklet to their nestlings at Triangle Island between mid-May and the end of June, 1996 to 2008. To control for inter-annual variation, all raw proportional data were converted to deviations from each year's mean, which was set to 0 . The zero-centred data were then pooled across all years, for each sampling session. The amount of E. pacifica delivered declined with date, while $T$. spinifera increased with date; $T$. inspinata was generally consistent across dates except for a sharp spike in the middle of June

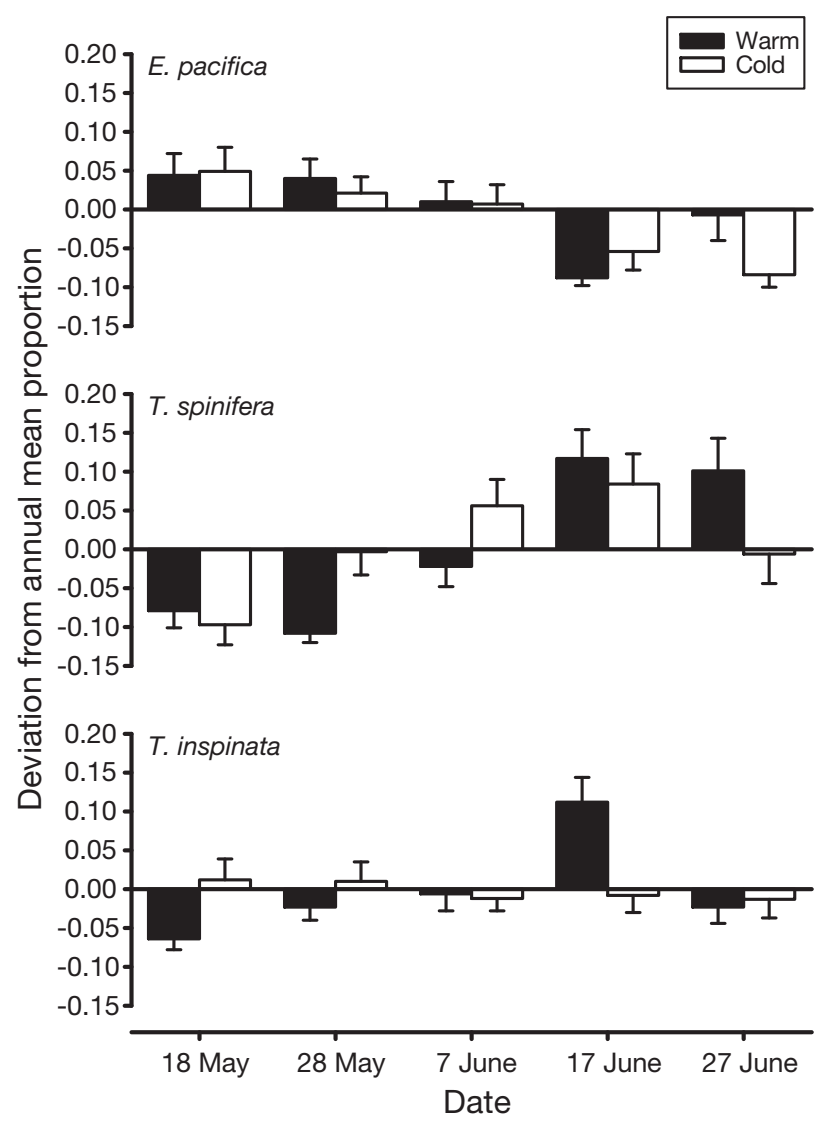

Fig. 7. Ptychoramphus aleuticus. Within-season variation (mid-May to end June) in the proportion of mean biomass $( \pm 1$ SE) comprised of Euphausia pacifica, Thysanoessa spinifera and T. inspinata in food loads delivered by Cassin's auklet to their nestlings at Triangle Island. Data were subdivided into warm years (1996 to 1998 and 2003 to 2006) and cold years (1999 to 2002 and 2007 to 2008). To control for inter-annual variation, all raw proportional data were converted to deviations from each year's mean, which was set to 0 . The zerocentred data were then pooled across all warm or cold years, for each sampling session. While the seasonal pattern of delivery did not vary among years for E. pacifica, the pattern did vary for both Thysanoessa spp.

Table 3. Ptychoramphus aleuticus. Results of AICc (Akaike's information criterion, corrected) model comparisons to explain variation in the annual percentage of Cassin's auklet nestlings that survived from hatching to fledging in relation to diet composition. Nc: Neocalanus cristatus; Ep: Euphausia pacifica; Ts: Thysanoessa spinifera; Ti: Thysanoessa inspinata. The euphausiids component of nestling diets had little effect on survival. AIC $w$ : AIC weight; $k$ : number of parameters in the model

\begin{tabular}{|lcccc|}
\hline Model & $\mathrm{R}^{2}$ & $\Delta \mathrm{AIC} c$ & $\mathrm{AIC} w$ & $k$ \\
\hline $\mathrm{Nc}+\mathrm{Nc}^{2}$ & 0.48 & 0.00 & 0.98 & 4 \\
$\mathrm{Nc}+\mathrm{Nc}^{2}+\mathrm{Ts}+\mathrm{Ts}^{2}$ & 0.57 & 8.86 & 0.01 & 6 \\
$\mathrm{Nc}+\mathrm{Nc}^{2}+\mathrm{Ti}+\mathrm{Ti}^{2}$ & 0.55 & 9.56 & 0.01 & 6 \\
$\mathrm{Nc}+\mathrm{Nc}^{2}+\mathrm{Ep}+\mathrm{Ep}^{2}$ & 0.52 & 10.69 & 0.00 & 6 \\
\hline
\end{tabular}


Table 4. Ptychoramphus aleuticus. Results of AICc (Akaike's information criterion, corrected) model comparisons to explain variation in the annual mean Cassin's auklet fledging mass in relation to diet composition. Nc: Neocalanus cristatus; Ep: Euphausia pacifica; Ts: Thysanoessa spinifera; Ti: Thysanoessa inspinata. The best-supported model included only $N$. cristatus, although the model also including $T$. inspinata was also strongly supported $(\mathrm{AIC} C \leq 2.0)$. AICw: AIC weight; $k$ : number of parameters in the model

\begin{tabular}{|lcccc|}
\hline Model & $\mathrm{R}^{2}$ & $\Delta \mathrm{AIC} C$ & $\mathrm{AIC} w$ & $k$ \\
\hline $\mathrm{Nc}+\mathrm{Nc}^{2}$ & 0.83 & 0.00 & 0.65 & 4 \\
$\mathrm{Nc}+\mathrm{Nc}^{2}+\mathrm{Ti}+\mathrm{Ti}^{2}$ & 0.92 & 1.37 & 0.33 & 6 \\
$\mathrm{Nc}+\mathrm{Nc}^{2}+\mathrm{Ep}+\mathrm{Ep}^{2}$ & 0.86 & 8.52 & 0.01 & 6 \\
$\mathrm{Nc}+\mathrm{Nc}^{2}+\mathrm{Ts}+\mathrm{Ts}^{2}$ & 0.86 & 9.28 & 0.01 & 6 \\
\hline
\end{tabular}

euphausiid species received support, while for fledging mass, the model including Thysanoessa inspinata in addition to $N$. cristatus also received strong support $($ AIC $c \leq 2.0)$. Thus, there was no evidence that increased amounts of euphausiids in diets increased survival probabilities, but there was evidence of a meaningful, additive effect on fledging mass for greater amounts of $T$. inspinata as a secondary prey item (Fig. 8).
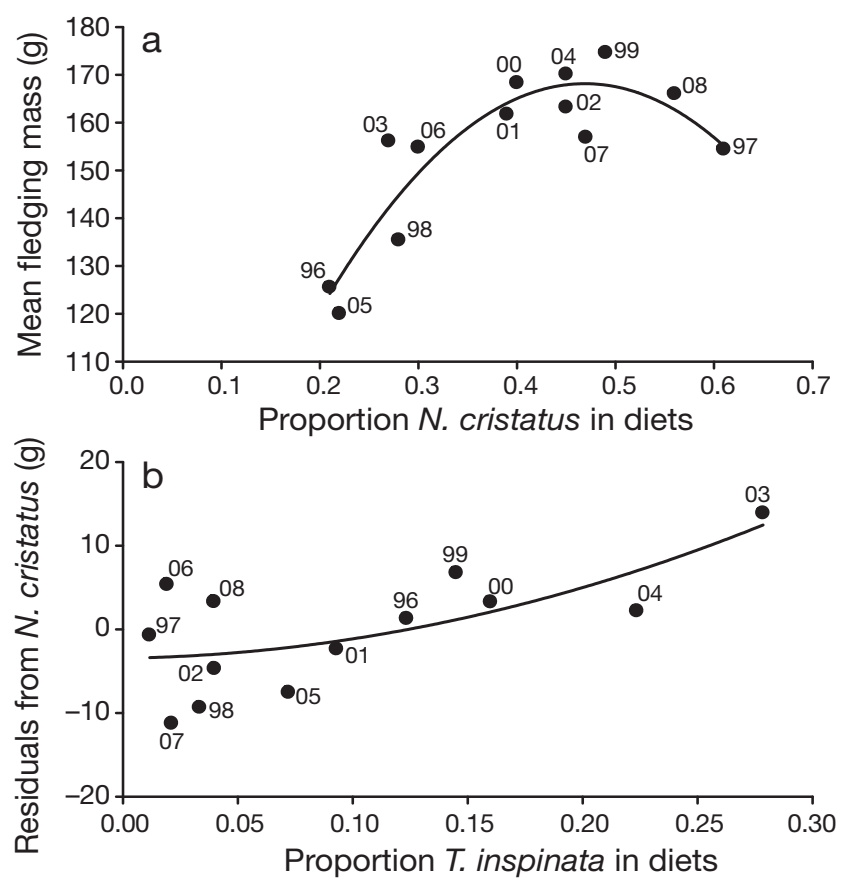

Fig. 8. Ptychoramphus aleuticus. (a) Annual mean fledging mass of Cassin's auklet offspring in relation to the mean proportion of biomass comprised of Neocalanus cristatus delivered to nestlings in that year. (b) Residuals from the relationship between $N$. cristatus and the mean fledging mass against the mean proportion of biomass comprised of Thysanoessa inspinata delivered in that year. Note that fledging mass increases very strongly with increasing $N$. cristatus, while $T$. inspinata (weakly) explains some of the residual variation

\section{DISCUSSION}

Recent work, updated here through 2008, has shown that the ocean climate in spring strongly influences the composition of the diets fed by Cassin's auklet Ptychoramphus aleuticus parents to their offspring at Triangle Island (Bertram et al. 2001, Hedd et al. 2002). In particular, nestling diets tend to be richer in the subarctic copepod Neocalanus cristatus during cold oceanic years, when the springtime period of residency of latestage $N$. cristatus copepodites in near-surface waters is delayed and prolonged (Mackas et al. 2007). This results in greater temporal overlap between the auklets' offspring-provisioning period and the period when the copepods are available to them. The auklets forage for $N$. cristatus along and seaward of the continental shelf break west of Triangle Island (Boyd et al. 2008), and they breed more successfully in years in which their diets include more $N$. cristatus (Hipfner 2008).

\section{Euphausiids in the diets of auklet nestlings}

\section{Species composition and age ratios}

The present study shows further that the 3 euphausiid species Euphausia pacifica, Thysanoessa spinifera and $T$. inspinata cumulatively form the major secondary prey items fed to Cassin's auklet nestlings at Triangle Island. Only 2 other euphausiids were recorded in diets in small amounts: T. gregaria (in $3 \mathrm{yr}$ ) and Nematoscelis difficilis (in $1 \mathrm{yr}$ ). Oceanic warming is widely expected to cause shifts in the distributions of zooplanktonic species (Richardson 2008), and in the northern CCS, such shifts periodically alter the zoogeographic affinities of the community as a whole (Mackas et al. 2001, 2004). The appearance in auklet diets of T. gregaria, normally a more southerly species (Brinton \& Townsend 2003), during the warm 2004 to 2006 period suggests that the birds' diets may gauge this sort of ecosystem change. In a similar fashion, the subtropical euphausiid Nyctiphanes simplex has appeared in Cassin's auklet diets in the central CCS during ocean-warming events (Ainley et al. 1996, Sydeman et al. 2001).

In general, juvenile Thysanoessa spinifera and $T$. inspinata were much rarer than adults in Cassin's auklet diets at Triangle Island, and juvenile Euphausia pacifica were absent altogether. Juvenile $T$. spinifera were more common in auklet diets in California (Abraham \& Sydeman 2004), especially in the south (Adams et al. 2004). The increasing use of juvenile $T$. spinifera from south to north could be due to earlier euphausiid spawning in southern sectors of the CCS, or to colony- 
specific differences in local oceanography, which determine the rate of advection of juveniles out of the birds' foraging range (Adams et al. 2004). The greater harvest of juveniles of $T$. spinifera versus E. pacifica, which is rare (California) or absent altogether (Triangle) in diets across the CCS, could be related to earlier (spring vs. summer) spawning by $T$. spinifera. This could make an initial cohort of juvenile $T$. spinifera available in May and June (Feinberg \& Peterson 2003, Lu et al. 2003, Pinchuk et al. 2008), when most auklets are provisioning.

Detailed information on the timing of spawning by Thysanoessa inspinata in the northern CCS is apparently lacking, perhaps because it is less abundant than Euphausia pacifica and T. inspinata (Mackas 1992, Mackas et al. 2001). However, juveniles were recorded in diets as early as late May in several years (1996 to 1998 and 2000). In contrast, T. spinifera juveniles were recorded in May only in 1998, suggesting that of the 2 species, $T$. inspinata might spawn slightly earlier. It remains open as to why juveniles of both species were reasonably common relative to adults up to 2000, but virtually absent thereafter. Earlier spawning during the very warm 1996 to 1998 period seems an unlikely explanation, because, if anything, T. spinifera spawns later in warm-water years off the Oregon coast (Feinberg \& Peterson 2003). Juvenile T. spinifera are advected seaward by upwelling (Lu et al. 2003), and thus might persist longer on the shelf during periods of delayed or weak upwelling and high SSTs. Note that from 1996 to 1998 euphausiids generally made up only small proportions of auklet diets and that independent data suggest that euphausiid abundance was in decline within the northern CCS through this period (Mackas et al. 2001).

\section{Annual variation}

Across the North Pacific, the distribution and abundance of the 3 euphausiids Euphausia pacifica, Thysanoessa spinifera and $T$. inspinata have been shown to respond in a complex manner to oceanographic variation (Tanasichuk 1998a,b, Marinovic et al. 2002, Mackas et al. 2004, Dorman et al. 2005, Taki 2007, Pinchuk et al. 2008), in some cases with detectable effects on the diets of euphausiid predators (Ainley et al. 1996, Brodeur et al. 2007).

At Triangle Island, the amounts of all 3 of these euphausiids delivered by Cassin's auklets to their offspring varied from year to year. In the case of Euphausia pacifica and Thysanoessa inspinata, this could not be related to spring SST either in the current year, or in the previous year. SST in the current year likewise had little effect on the amount of $T$. spinifera delivered.
Assuming that some mechanism links oceanographic conditions, such as the strength of upwelling (Mackas et al. 2001, Dorman et al. 2005), to the immediate abundance of euphausiids (Marinovic et al. 2002, Brinton \& Townsend 2003, Pinchuk et al. 2008), results of the present study may imply that the harvest of euphausiids does not strongly gauge variation in their abundance within the 10 s of kilometres over which auklets forage from Triangle Island (Boyd et al. 2008). Likewise, inter-annual variation in the diet of a numerically more important euphausiid predator in the CCS, the Pacific hake Merluccius productus, did not match year-to-year variation in the abundance of $T$. spinifera (Tanasichuk 2002). It is possible that the euphausiids are superabundant relative to the birds' harvest in this marine system largely controlled by bottom-up processes (Ware \& Thomson 2005).

Yet there was one discernible effect of ocean climate on the annual harvest of euphausiids by Cassin's auklets: nestling diets tended to be richer in Thysanoessa spinifera in the year following a year with low spring SSTs. The simplest explanation is that the production of a strong (annual) cohort in one year created a strong pulse of spawning adult biomass in the next (Tanasichuk 1998a, Feinberg \& Peterson 2003), the key assumption being that $T$. spinifera produces stronger cohorts in cold years. In support of this idea, the euphausiid spawning season off the Oregon coast is prolonged under cold conditions, with multiple rather than single peaks in egg production (Feinberg \& Peterson 2003) and larger brood sizes (Gomez-Gutierrez et al. 2007). In addition, larval Euphausia spp. and Thysanoessa spp. grow more quickly when food is more readily available to them (Pinchuk \& Hopcroft 2007), so that cohorts produced under cold conditions may have high survival rates because they experience favourable feeding conditions.

\section{Seasonal variation}

At Triangle Island, Cassin's auklets provisioned offspring with more Euphausia pacifica early in the season, but more Thysanoessa spinifera late in the season. This same dietary switch also occurs at colonies in California, where adult diets track a similar switch (Ainley et al. 1996). In contrast, the harvest of $T$. inspinata at Triangle Island was consistent across the season, except for a large increase in mid-June. However, whereas the seasonal decrease in the harvest of $E$. pacifica was consistent from year to year, the seasonal pattern of harvest of the 2 Thysanoessa spp. varied from year to year. Comparisons of the patterns in warm years versus cold years suggested that there was an effect of ocean climate. 
In the case of Thysanoessa inspinata, the amount delivered to auklet nestlings was very consistent across the season in cold-water years, while a midJune spike in its harvest occurred only in warm-water years. In the case of $T$. spinifera, the pattern of increasing use was evident in both cold- and warm-water years, but the harvest peaked slightly earlier in cold years (early-to-mid June) than in warm years (mid-tolate June). The increased use, relative to each year's mean biomass, of the 2 species of Thysanoessa from mid-June onwards coincided exactly with the time when Neocalanus cristatus, the auklets' primary prey, virtually disappeared from diets (Bertram et al. 2001, Hipfner 2008).

Cassin's auklets thus showed 2 patterns of seasonal prey switching at Triangle Island: (1) between Neocalanus cristatus early and Thysanoessa spp. late, but mainly in warm-water years (at least to the end of June, when sampling ended). This switch is easily explained by the earlier life-cycle timing of Neocalanus spp. in warm years, when this very profitable prey type migrates out of near-surface waters, thus out of the auklets' reach, at an earlier date (Bertram et al. 2001, Mackas et al. 2007). (2) In any year a switch occurs between Euphausia pacifica early in the season and T. spinifera late in the season. Previously, Abraham \& Sydeman (2006) proposed several hypotheses, not mutually exclusive, to account for the auklets' seasonal switch from E. pacifica to T. spinifera. That the same switch occurs regularly in the southern (Adams et al. 2004), central (Abraham \& Sydeman 2006) and northern (present study) CCS argues for a common underlying cause, and I will briefly consider each of their 4 hypotheses in turn.

(1) It occurs because Euphausia pacifica is seasonally advected out of the auklets' foraging range by upwelling: many factors influence the spatial distribution of zooplankton off the west coast of North America (Mackas \& Coyle 2005). In areas of sympatry, E. pacifica is more oceanic than Thysanoessa spinifera (Brinton \& Townsend 2003, Lu et al. 2003, Pinchuk et al. 2008), and, in the northern CCS, E. pacifica is displaced further seaward as the strength of upwelling increases through the summer (Lu et al. 2003). These observations match the assumptions underlying this hypothesis, although whether they hold within the birds' foraging range at Triangle Island remains to be tested. However, we might predict, based on this hypothesis, that E. pacifica would remain important in auklet diets until late in warm years, if upwelling is reduced or delayed. There was little support for this idea. Further, the abundance of E. pacifica declines seasonally in shelf habitats, while that of $T$. spinifera does not, even in the downwelling-driven Alaska Gyre (Coyle \& Pinchuk 2005), where an important euphausiid predator, walleye pollack Theragra chalcogramma, also seasonally increases its take of $T$. spinifera (Adams et al. 2007).

(2) It is a result of active prey choice, based on fitness costs and benefits: In the central CCS, increased use of the more abundant Euphausia pacifica by Cassin's auklets early in the season is linked to earlier laying (Abraham \& Sydeman 2004), while increased use of the less abundant Thysanoessa spinifera late is linked to faster offspring growth (Abraham 2008). At Triangle Island, however, diets richer in $T$. spinifera were not linked to increases in survival or fledging mass. The alternative, that the auklets simply prefer T. spinifera over E. pacifica given the choice, is difficult to evaluate without independent data on the 2 euphausiids' relative abundance within the birds' foraging range. However, Ainley et al. (1996) suggested that T. spinifera may be the more profitable of the 2 species as prey for Cassin's auklets, and, at Triangle Island, this species is harvested in greatest quantities by the auklets during the period of peak demand late in the provisioning period, especially in warm-water years after $\mathrm{NeO}$ calanus cristatus becomes less available.

(3) It is a result of passive prey choice, due to seasonal contraction of the auklets' foraging range: as a group, the euphausiids preyed on by Cassin's auklets at Triangle Island show wide variation in $\delta^{13} \mathrm{C}$ stable isotope values (Davies et al. 2009). This suggests that the birds forage widely for them. Furthermore, the mean $\delta^{13} \mathrm{C}$ value of Neocalanus cristatus $(-20.13 \%$ ) is closer to that of Euphausia pacifica (-19.30\%) than that of Thysanoessa spinifera (-18.58\%), perhaps indicating greater distributional overlap (M. Hipfner unpubl. data). It is possible then that E. pacifica is taken in large amounts in or near areas where the birds forage primarily for $N$. cristatus early in the season. The tendency for the more neritic $T$. spinifera to become especially important late in warm years, when the birds largely cease harvesting $N$. cristatus, is also consistent with this hypothesis. However, it also predicts that E. pacifica will remain important in diets until late in cold years, because $N$. cristatus remains important. There was little evidence of this. Further, the season-long use of $N$. cristatus in cold years suggests that the auklets do not necessarily contract their foraging range-in this system, prey quality may trump foraging distance.

(4) It results from the auklets' avoiding competition with other summertime Euphausia pacifica predators: this hypothesis is very difficult to evaluate, but based on the idea that Pacific hake specifically target E. pacifica as the fish move north in late spring and summer. However, both Pacific hake and Pacific herring Clupea harengus, 2 of the more numerically important euphausiid predators in the northern CCS, eat more of 
the less abundant Thysanoessa spinifera than the more abundant E. pacifica (Tanasichuk 2002).

\section{Fitness correlates of euphausiids in diets}

The amount of Neocalanus cristatus in their diets previously was found to be the key factor affecting yearly variation in the percentage survival and mean fledging masses of Cassin's auklets at Triangle Island (Hipfner 2008). In both cases, this remains the most parsimonious explanation with the addition of 2 more years. There was little additive benefit of including more of either Euphausia pacifica or Thysanoessa spinifera on either fitness measure, despite that increased amounts of $T$. spinifera in diets previously were linked to higher growth rates (Abraham 2008). However, there was a relatively small additive effect on fledging mass (but not survival) of including more T. inspinata. This euphausiid increased dramatically in nestling diets in the middle of June in warm years, at the time when auklets ceased delivering $N$. cristatus. Unfortunately, there is almost no information on the ecology of $T$. inspinata in the northern CCS, and that precludes an assessment of what factors ultimately influence its availability to Cassin's auklets. It appears, however, that SST does not have a strong effect. ern CCS to replace the predictable and high-quality prey item $N$. cristatus in feeding the very large Cassin's auklet populations in the Scott Islands. If true, then we can expect that continued warming of the marine environment around this archipelago will have strong deleterious effects on these large populations. Continued monitoring of this and other seabird populations in the CCS will be important as we attempt to document and understand changes to marine ecosystem functioning as a result of future climatic warming.

Acknowledgements. Thanks to the many field workers who helped to collect these data, and to M. Court, J. Higham, C. Smith, as well as West Coast Helicopters and the Canadian Coast Guard, for top-notch logistical support. M. Galbraith, Institute of Ocean Sciences, Sidney, deserves special thanks for enumerating prey items in the Cassin's auklet 'gurge' samples. The research was conducted under a Scientific Permit from the Canadian Wildlife Service and an Animal Care Permit from Simon Fraser University. Funding was provided by the 'Nestucca' Oil Spill Trust Fund, the Climate Change Action Fund, the World Wildlife Fund Canada, the Science Horizons, Migratory Bird, and Birds Oiled at Sea programs of Environment Canada, the Natural Sciences and Engineering Research Council of Canada (grants to F. Cooke), and the Centre for Wildlife Ecology. Finally, I thank Christine Abraham for her thorough and thoughtful review of the draft manuscript, and 3 anonymous referees for constructive criticism during the review process.

\section{LITERATURE CITED}

\section{Implications for Cassin's auklets in the northern CCS}

The bulk of the global population of Cassin's auklets breeds in the Scott Islands archipelago, off the coast of British Columbia (Rodway 1991). In this region, ocean climate strongly influences the birds' demography (Bertram et al. 2001, 2005, Hipfner 2008, Morrison 2009, Hipfner et al. in press). An adequate supply of Neocalanus cristatus appears to be critical for successful breeding by Cassin's auklets in this system, and a warming ocean is likely to result in more frequent and more severe temporal mismatches between the auklet predator and the copepod prey.

In the southern and central CCS, where Euphausia pacifica and Thysanoessa spinifera are their most important prey (Abraham \& Sydeman 2004, Adams et al. 2004), all Cassin's auklet populations are relatively small and in precipitous decline due to ocean warming (Lee et al. 2007, Wolf et al. 2009). While euphausiids, in general, are less important to auklets in the northern CCS, there was some fitness benefit associated with including more T. inspinata in diets, but no overt benefit associated with including more of E. pacifica or $T$. spinifera. However, compared to Neocalanus cristatus, the effect of $T$. inspinata was small. Thus, there appears to be nothing presently available in the north-

Abraham CL (2008) Relative contribution of euphausiid prey species and timing of breeding to Cassin's auklet Ptychoramphus aleuticus growth: within-season effects. J Avian Biol 39:178-188

Abraham CL, Sydeman WJ (2004) Ocean climate, euphausiids and auklet nesting: inter-annual trends and variation in phenology, diet and growth of a planktivorous seabird, Ptychoramphus aleuticus. Mar Ecol Prog Ser 274:235-250

Abraham CL, Sydeman WJ (2006) Prey-switching by Cassin's auklet Ptychoramphus aleuticus reveals seasonal climaterelated cycles of Euphausia pacifica and Thysanoessa spinifera. Mar Ecol Prog Ser 313:271-283

Adams J, Takekawa JY, Carter HR (2004) Stable foraging areas and variable chick diet in Cassin's auklets (Ptychoramphus aleuticus) off southern California. Can J Zool 82:1578-1595

Adams CF, Pinchuk AI, Coyle KO (2007) Seasonal changes in the diet composition and prey selection of walleye pollock (Theragra chalcogramma) in the northern Gulf of Alaska. Fish Res 84:378-389

Aebischer NJ, Coulson JC, Colebrook JM (1990) Parallel long-term trends across four marine trophic levels and weather. Nature 347:753-755

Ainley DG, Spear LB, Allen SG (1996) Variation in the diet of Cassin's auklet reveals spatial, seasonal, and decadal occurrence patterns of euphausiids off California, USA. Mar Ecol Prog Ser 137:1-10

> Anderson PJ, Piatt JF (1999) Community reorganization in the Gulf of Alaska following ocean climate regime shift. Mar Ecol Prog Ser 189:117-123

Bertram DF, Mackas DL, McKinnell SM (2001) The seasonal 
cycle revisited: interannual variation and ecosystem consequences. Prog Oceanogr 49:283-307

Bertram DF, Harfenist A, Smith BD (2005) Ocean climate and El Niño impacts on survival of Cassin's auklets from upwelling and downwelling domains of British Columbia. Can J Fish Aquat Sci 62:2841-2853

Boyd WS, Tranquilla LM, Ryder JL, Shisko SG, Bertram DF (2008) Variation in marine distributions of Cassin's auklets (Ptychoramphus aleuticus) breeding at Triangle Island, British Columbia. Auk 125:158-166

Brinton E, Townsend A (2003) Decadal variability in abundances of the dominant euphausiid species in southern sectors of the California Current. Deep Sea Res II 50: 2449-2472

Brodeur RD, Pearcy WG (1992) Effects of environmental variability on trophic interactions and food web structure in a pelagic upwelling ecosystem. Mar Ecol Prog Ser 84: 101-119

Brodeur RD, Daly EA, Schabetsberger RA, Mier KL (2007) Interannual and interdecadal variability in juvenile coho salmon (Oncorhynchus kisutch) diets in relation to environmental changes in the northern California Current. Fish Oceanogr 16:395-408

Burnham KP, Anderson DR (2002) Model selection and multimodel inference: a practical information-theoretic approach. Springer, New York

Coyle KO, Pinchuk AI (2005) Seasonal cross-shelf distribution of major zooplankton taxa on the northern Gulf of Alaska shelf relative to water mass properties, species depth preferences and vertical migration behavior. Deep Sea Res II 52:217-245

> Croll DA, Marinovic B, Benson S, Chavez FP, Black N, Ternullo R, Tershy BR (2005) From wind to whales: trophic links in a coastal upwelling system. Mar Ecol Prog Ser 289:117-130

Davies WE, Hipfner JM, Hobson KA, Ydenberg RC (2009) Seabird seasonal trophodynamics: isotopic patterns in a community of marine birds. Mar Ecol Prog Ser 382: 211-219

DFO (Department of Fisheries and Oceans Canada) (2008) State of the Pacific Ocean 2007. Can Sci Advis Rep 2008/028, DFO, Sidney, British Columbia

> Dorman JG, Bollens SM, Slaughter AM (2005) Population biology of euphausiids off northern California and effects of short time-scale wind events on Euphausia pacifica. Mar Ecol Prog Ser 288:183-198

> Durant JM, Anker-Nilssen T, Stenseth NC (2003) Trophic interactions under climate fluctuations: the Atlantic puffin as an example. Proc R Soc Lond B 270:1461-1466

Edwards M, Richardson AJ (2004) Impact of climate change on marine pelagic phenology and trophic mismatch. Nature 430:881-884

Feinberg LR, Peterson WT (2003) Variability in duration and intensity of euphausiid spawning off central Oregon, 1996-2001. Prog Oceanogr 57:363-379

Gomez-Gutierrez J, Feinberg LR, Shaw TC, Peterson WT (2007) Interannual and geographical variability of the brood size of the euphausiids Euphausia pacifica and Thysanoessa spinifera along the Oregon coast (1999-2004). Deep Sea Res I 54: 2145-2169

> Hedd A, Ryder JL, Cowen LL, Bertram DF (2002) Inter-annual variation in the diet, provisioning and growth of Cassin's auklet at Triangle Island, British Columbia: responses to variation in ocean climate. Mar Ecol Prog Ser 229:221-232

> Hipfner JM (2008) Matches and mismatches: ocean climate, prey phenology and breeding success in a zooplanktivorous seabird. Mar Ecol Prog Ser 368:295-304

Hipfner JM, McFarlane-Tranquilla LA, Addison B (in press)
Experimental evidence that both timing and parental quality affect breeding success in a zooplanktivorous seabird. Auk 127

Lee DE, Nur N, Sydeman WJ (2007) Climate and demography of the planktivorous Cassin's auklet Ptychoramphus aleuticus off northern California: implications for population change. J Anim Ecol 76:337-347

Lu BW, Mackas DL, Moore DF (2003) Cross-shore separation of adult and juvenile euphausiids in a shelf-break alongshore current. Prog Oceanogr 57:381-404

- Mackas DL (1992) Seasonal cycle of zooplankton off southwestern British Columbia: 1979-1989. Can J Fish Aquat Sci 49:903-921

> Mackas DL, Coyle KO (2005) Shelf-offshore exchange processes, and their effects on mesozooplankton biomass and community composition patterns in the northeast Pacific. Deep Sea Res II 52:707-725

> Mackas DL, Thomson RE, Galbraith M (2001) Changes in the zooplankton community of the British Columbia continental margin, 1985-1999, and their covariation with oceanographic conditions. Can J Fish Aquat Sci 58:685-702

Mackas DL, Peterson WT, Zamon JE (2004) Comparisons of interannual biomass anomalies of zooplankton communities along the continental margins of British Columbia and Oregon. Deep Sea Res II 51: 875-896

Mackas DL, Batten S, Trudel M (2007) Effects on zooplankton of a warmer ocean: recent evidence from the Northeast Pacific. Prog Oceanogr 75:223-252

> Marinovic BB, Croll DA, Gong N, Benson SR, Chavez FP (2002) Effects of the 1997-1999 El Niño and La Niña events on zooplankton abundance and euphausiid community composition within the Monterey Bay coastal upwelling system. Prog Oceanogr 54:265-277

Morrison KW (2009) Demographic consequences of early development and extreme climate events for alcids on Triangle Island, British Columbia. MSc thesis, Simon Fraser University, Burnaby, BC

> Piatt JF, Sydeman WJ, Wiese F (2007) Introduction: a modern role for seabirds as indicators. Mar Ecol Prog Ser 352:199-204

> Pinchuk AI, Hopcroft RR (2007) Seasonal variations in the growth rates of euphausiids (Thysanoessa inermis, $T$. spinifera, and Euphausia pacifica) from the northern Gulf of Alaska. Mar Biol 151:257-269

> Pinchuk AI, Coyle KO, Hopcroft RR (2008) Climate-related variability in abundance and reproduction of euphausiids in the northern Gulf of Alaska in 1998-2003. Prog Oceanogr 77:203-216

Reid K, Murphy EJ, Croxall JP, Trathan PM (2004) Population dynamics of Antarctic krill Euphausia superba at South Georgia: sampling with predators provides new insight. In: Boyd IL, Wanless S, Camphuysen CJ (eds) Top predators in marine ecosystems: their role in monitoring and management. Cambridge University Press, Cambridge, p 249-261

> Richardson AJ (2008) In hot water: zooplankton and climate change. ICES J Mar Sci 65:279-295

Rodway MS (1991) Status and conservation of breeding seabirds in British Columbia. In: Croxall JP (ed) Supplement to the status and conservation of the world's seabirds. International Council for Bird Preservation, Cambridge, p 43-102

Springer AM, Roseneau DG (1985) Copepod-based food webs - auklets and oceanography in the Bering Sea. Mar Ecol Prog Ser 21:229-237

Stenseth NC, Ottersen G, Hurrell JW, Belgrano A (2004) Marine ecosystems and climate variation. Oxford University Press, Oxford 
Suntsov AV, Brodeur RD (2008) Trophic ecology of three dominant myctophid species in the northern California Current system. Mar Ecol Prog Ser 373:81-96

Sydeman WJ, Hester MM, Thayer JA, Gress F, Martin P, Buffa J (2001) Climate change, reproductive performance and diet composition of marine birds in the southern California Current system, 1969-1997. Prog Oceanogr 49:309-329

Sydeman WJ, Bradley RW, Warzybok P, Abraham CL and others (2006) Planktivorous auklet Ptychoramphus aleuticus responses to ocean climate, 2005: Unusual atmospheric blocking? Geophys Res Lett 33, L22S09, doi: 10.1029/2006GL026736

Taki K (2007) Seasonal changes in distribution and abundance of euphausiids in the coastal area of north-eastern Japan. Fish Sci 73:522-533

Tanasichuk RW (1998a) Interannual variations in the population biology and productivity of Euphausia pacifica in Barkley Sound, Canada, with special reference to the 1992

Editorial responsibility: Rory Wilson,

Swansea, UK and 1993 warm ocean years. Mar Ecol Prog Ser 173: 163-180

Tanasichuk RW (1998b) Interannual variations in the population biology and productivity of Thysanoessa spinifera in Barkley Sound, Canada, with special reference to the 1992 and 1993 warm ocean years. Mar Ecol Prog Ser 173: 181-195

Tanasichuk RW (2002) Implications of interannual variability in euphausiid population biology for fish production along the south-west coast of Vancouver Island: a synthesis. Fish Oceanogr 11:18-30

Ware DM, Thomson RE (2005) Bottom-up ecosystem trophic dynamics determine fish production in the northeast. Pac Sci 308:1280-1284

Wolf SG, Sydeman WJ, Hipfner JM, Abraham CL, Tershy B, Croll DA (2009) Range-wide reproductive consequences of ocean climate variability for the seabird Cassin's auklet. Ecology 90:742-753

Submitted: May 6, 2009; Accepted: July 8, 2009

Proofs received from author(s): September 4, 2009 